\title{
The Relationships between Social Media Facebook and Family Divorce (Study in Middle - Lass Society at Padang, West Sumatra-Indonesia)
}

\author{
Reza Fahmi ${ }^{1}$, Prima Aswirna ${ }^{2}$ \\ 1,2Universitas Islam Negeri Imam Bonjol Padang \\ ${ }^{1}$ rezafahmi@uinib.ac.id, ${ }^{2}$ primaaswirna@uinib.ac.id
}

\begin{abstract}
Social media such as Facebook is assumed to have become a means of social interaction at this time. However, social media can also be one of the triggers for disputes between married couples that lead to divorce. Furthermore, the purpose of this study is: (1) To get an idea of the characteristics of Facebook social media users in the middle class in the city of Padang. (2) Obtaining a picture of divorce that occurs in the middle-class society in the city of Padang. (3) Finding evidence of the relationship between the use of Facebook and divorce in middle-class families in the city of Padang. The population in the study was 368 people. While the study sample was 191 people, this study uses a quantitative descriptive approach. The technique of collecting data through psychological scales and interviews. Sampling technique using simple random sampling. Data analysis techniques using the Pearson correlation. The study results found that $\mathrm{r}_{\text {count }}=3.86<\mathrm{r}$ table 5.92 , which means there is no relationship between the use of Facebook and divorce in the family in the middle social class in the city of Padang.
\end{abstract}

Keywords

Social Media, Facebook, Family Divorce and Middle-Class Societ

Article Received: 10 August 2020, Revised: 25 October 2020, Accepted: 18 November 2020

\section{Introduction}

The virtual world is a globally connected, computer-supported, computer-accessible, multidimensional, artificial, or virtual reality. In this reality, where each computer is a window, visible or audible objects are not physical and are not representations of physical objects. Instead, they are styles, characters, and actions of creating data and producing pure information. Cyberspace refers to the metaphorical world using many forms of electronic communication, which are used in the internet world. The virtual world offers the opportunity to form a real community, where people share the same interests and are met by electronics. This new electronic media has made massive changes in society with all its positive and negative impacts.

The virtual world then gave birth to a new society called the cyberspace community or internet community. Members of contemporary society are scattered worldwide, and every day there are about 5,000 people, very free to hold discussions and exchange information interactively. That is why the internet is called interactive media because everyone can access (download) messages via the internet without obstacles and without knowing national borders, and without being controlled by the state. The presence of cyberspace that uses the internet as a medium to enter is an empirical reality of an industrial revolution. 4.0. Like it and not, we have been at the forefront of advances in science and technology that make us an integral part of the virtual world we face today. So it is not surprising that we do not only have friends, friends, lovers, or partners that they do not exist physically. But we often meet them in cyberspace through social media in the form of; Facebook, Instagram or Twitter, and so on.

Sites like Facebook are currently blamed for onethird of divorce cases. Facebook is increasingly being used as a source of evidence in divorce cases. A legal consultant in India says 33 percent of the five thousand divorce cases in the country are due to Facebook. For example, most people get back in touch with their ex or new person and start texting each other without feeling guilty and guilty to their legal partner. This is what ultimately causes problems. "If someone wants to have an affair or have sex with the opposite sex, then social networking is the easiest place to do it," said the managing director of the legal consultancy, quoted from Mid Day, Tuesday (Republika Daily 14/8/2018). Facebook's most 
common reason triggers relationship breakdowns is that partners encounter flirtatious messages, photos of their partner at a new event, or their partner takes an affectionate image with someone they don't know. Another current reason that triggers today's divorce is the increasing demands of couples. After getting married, some couples want to go on vacation to the Himalayas, have adventures across Kalimantan, have expensive trips, or whatever activities they have never experienced at a young age.

Stigmatization assumes that divorce often occurs in society because social media has become an inevitable fact. Of course, this is something that can be accepted, when the head of the Solok Religious Court, West Sumatra stated that, "... around 25 percent or 110 cases out of 316 cases of divorce filed by women) and 118 cases of divorce talak (a divorce request filed by a man) the cause of constant disputes comes from social media "Muhammad Fauzan. Furthermore, Muhammad Fauzan explained," ... Divorce cases that occur due to continuous disputes triggered by the use of social media have shown an increasing trend in the last three years, "he said, in Solok, Tuesday (Republika Daily News Paper, 4/2 // 2020). Thus, social media, including Facebook, also tends to contribute negatively to the pattern of relationships between husbands and wives suspected of giving birth to divorce. However, it must also be acknowledged that social media contributes significantly to intense communication between people who have not been in touch for a long time to bring back the interaction between them.

Given that sometimes they are physically far apart from one another. So that, Social media (often misrepresented as social media) is an online medium where users can easily participate, share and create content on blogs, social networks, wikis, forums, and virtual worlds. Blogs, social networks, and wikis are the most common forms of social media worldwide. So, Social media has been developed in society in the current era of the Industrial Revolution 4.0. All sites offer convenience for users to communicate intensely, even though they are physically far apart. Not only limited to the area between one city and another city. Even between countries with other countries. So what was described by Giddens
(2010) in his book "Sociology" world without borders (borderless)? So that capital, services and goods, events, and so on can move from one place to another in a brief period. What events occur in a country on a particular continent region can be seen and witnessed by other people who are far from the incident's location. It can be disseminated to anyone who is desired through social media, What-sup, Telegram, Line, Facebook, etc. Of course, this will facilitate information to be spread massively to anyone existing social media users. So it is not surprising that hoax news is easily applied as irresponsible and challenging to prove truthful messages.

Furthermore, this research specializes in reviewing Facebook social media as a friendship site where many people have used Facebook. So that Facebook users have reached hundreds of millions of people, this shows that Facebook has become part of the lifestyle and social behavior during society. This is evidenced by the frequency of people updating their status on Facebook. Whatever activities they run are uploaded to the internet and social media via Facebook. For example: when people eat, when people are traveling, when people are grieving, and even when people break out yet though they are uploaded as part of life history, they need to convey not only to friends on campus but also to others they know wherever they are. Thus Facebook has a dominant role in building new patterns of social interaction, where if people want to meet other people, they need to greet each other in the real world. Whereas now they can greet each other, even though their physical distance is far apart.

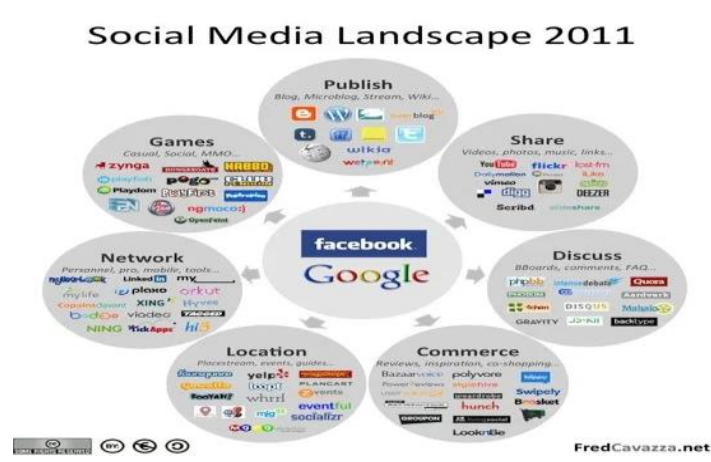

Figure 1. The most widely used social media platform in the world ( We Area Social and Hootsuite) 
On the other hand, like social media, Facebook also has many negative impacts that are detrimental to society. Facebook is used as a media for the spread of hoaxes that misguided information to the public about a problem amid the community. For example, lecturers who spread the issue of dividing the statement of truth about "people power." Furthermore, the lecturer in question stated, "The price of people's lives if people power cannot be avoided: the police shot one citizen, must be paid with ten policemen killed. Using kitchen knives, machetes, crowbars, axes, car wheel locks, tasting, fire paint, and their families". Next, give an example of news that cannot be verified but has been uploaded to social media:

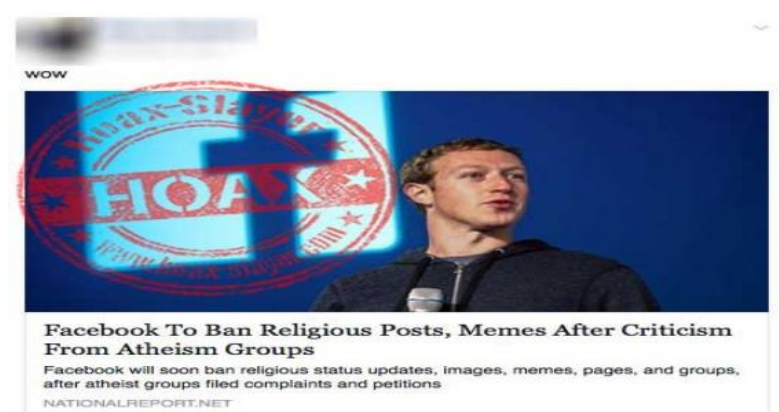

Figure 2. Examples of communication that are not known to be redacted and cannot be confirmed (Hoax).

However, what you want to study in this study is: "Is there a connection between Facebook and divorce in the family" - considering that so many have claimed that divorce is caused by jealousy from both the husband and wife, which leads to divorce. Of course, the allegations need to be proven through an in-depth study in the research. Furthermore, the purpose of this study is: (1) To get an idea of the characteristics of Facebook social media users in the middle class in the city of Padang. (2) Obtain a picture of divorce that occurs in the middle-class society in the city of Padang. (3) Proving the relationship between the use of Facebook and divorce in middle-class families in the city of Padang.

\section{Theoretical Background}

\section{Facebook as Social Media}

Media can provide various information needed and determine certain realities, thoughts, and views about the world and its social reality. The media is part of a cultural industry tied to the community communication system, managed as an industrial organization with its interests and tendencies. The media's interests and preferences are determined by the media environment's social, economic, cultural, and political systems. This determines the framework construction, work, and behavior of managing the media and mass media.

In simple terms, social media can be defined as an internet medium that allows users to represent themselves and interact, collaborate, share, communicate with other users, and form social bonds virtually. Social media is a media designed to facilitate interactive social interactions based on technology. The internet has changed disseminating information from previously broadcast media monologue (one to many audiences) to social media dialogue (many audiences to many audiences). Social media also supports the democratization of information and knowledge that changes audiences' behavior from previously consuming content to producing content. In an increasingly advanced era, the longer the way to communicate and convey human information is increasingly developing. One of the changes today is due to the emergence of social media or social media. From day to day, the use of social media is increasing rapidly with the increasing number of new social media appearing along with the easier internet access in homes and the development of smartphone and tablet technology. Internet users can access the internet 24 hours from their personal computers in their homes via smartphones or tablets. So $d$ of the natural nature of modern democracy, communication between political actors and citizens is hard to do face to face. The media is no longer a mere means of communication, but at the same time as a public space for political deliberation in which citizens can participate actively, thanks to technological advances and the increasingly independent media economy, so that it is free from state intervention.

Therefore, social media transmit the information as is but actively participates in addressing political realities as political actors for themselves. The media supervises and evaluates political processes that the public deems necessary 
to know. This role is expected to be played by the media in advancing democracy. Experience proves that media and political relations are interpenetrative and mutually influencing. This means that the relationship is not always cooperative, but it can also contradict or have different views. However, this relationship's essential thing is that the media can be independent to carry out their critical function or even become a propaganda tool for the political elite. Because of currently mediated politics, political elites are increasingly aware of the importance of media access for their self-image.

However, the development of social media has changed the communication patterns of today's society. People now like to write comments on any issue, personal and social, on social media. The writings that are written on the network will be immediately spread to various parts of the world. The dissemination of information is no longer only through word of mouth, but also through social media. In general, media is a social institution. However, on this occasion, the press is positioned as a political institution in the fourth estate context, as stated by Edmund Burke. Setting the media as a political institution does not mean to remove it as a social institution

In simple terms, the term media can be explained as a means of communication as the definition has been known. Sometimes this media tends to be closer to its mass nature because it can be seen from the various theories that have emerged in mass communication. The word social in social media, in view, should be approached by the realm of sociology. The term social refers to social relations. Social relations itself can be seen in the category of social action and social relations. Two basic notions of meditation and social have been explained, but it is not easy to define social media based solely on technological devices. An approach to social theories is needed that clarifies what distinguishes between social media and other media on the internet before concluding what is meant by social media. Social media is a medium on the internet that allows users to represent themselves and interact, collaborate, share, communicate with other users, and form virtual social bonds. (Rulli Nasrullah, 2015: 13 ).
Facebook is a social networking site (social networking) or an online social networking service, allowing users to interact with each other and share information worldwide (Arifin, 2009: 30). Facebook is a social networking website where users can join communities such as cities, work, schools, and regions to connect and interact with other people. People can also add their friends, send messages, and update their profiles so that others can see about themselves (Saputra, 2004). Facebook, or abbreviated as FB, is a popular social networking website launched on February 4, 2004. Mark Zuckerberg founded Facebook. , a Harvard student born on May 14, 1984, and a former Ardsley High School student (Geisha, 2010: 35). From the definition that has been described above, it can be concluded that Facebook is a social networking site that allows users to interact socially around the world. According to Horrigan (2000: 25), two essential things must be observed to determine the intensity of a person's internet use, namely the frequency of the internet that is often used and the length of time it is used access the internet. The Graphic, Visualization \& Usability Center, the Georgia Institute of Technology (in Michell: 2002: 25) classifies internet users into three categories based on the intensity of the internet used: 1) Heavy users (more than 40 hours per month). 2) Medium users (between 10 to 40 hours per month) 3) Light users (less than 10 hours per month). Thus Facebook is a social networking site that is in demand by all groups of society, one of which is a student. Facebook among students is not a strange thing anymore. For them, Facebook is a trend. The raises a new lifestyle for Facebook users, especially among students. Data on Alexa explains that Facebook is the number one social networking machine. In the order of all sites in the world, Facebook ranks 5th after yahoo, google, youtube, and windows live. The popularity of Facebook in Indonesia began in 2008 with an astonishing number of Facebook users, namely $618 \%$. According to data from The New York Times, as of April 2010, countries with the most Facebook users are the United States, United Kingdom, and Indonesia. Indonesian Facebook users have now reached at least 24 million or $10 \%$ of the total population of Indonesia

Looking at the data above, if Facebook is analogous to a "country," then Facebook can 
become the "most democratic country." Everyone is allowed to be citizens, from small children to adults, street children to professors, and unemployed to company commissioners. Everyone with different statuses and social strata can enter the "Facebook Country" very freely. Based on the description above, it can be concluded that Facebook social media is an internet medium that allows users to introduce/explore themselves and collaborate, share and communicate with other users, and form virtual social bonds.

Facebook users are often called Face bookers. The majority of Face bookers use Facebook to connect with family, relations, and friends. Facebook causes a network of relationships to expand because discoveries of relationships are always being created. Not only that, Facebook can open communication gates so that contacts can continue. Also, Facebook has a newsfeed facility that makes it easier for Face bookers to access information in an organized manner and reminders such as notifications of other Face booker friends' activities and messages like email are quite popular with many Face bookers.

Facebook can be a popular communication alternative. This is even more so for people who have a closed, shy, or quiet personality. Communicating via Facebook, there is no need to show yourself physically; for example, face to face. If you want to make friends with other Face bookers, click on the facility to add friends and verify. Facebook also has features and content that are varied and innovative (including parts for games, surveys, applications, and others). This is also what makes Facebook so popular with people that it becomes a social networking medium. Mark Zuckerberg wrote the reason for Facebook's evolution, namely: "Facebook's mission is to give people the power to share and make the world more open and connected. In the last four years, we've built new products that help people communicate more, such as photos, videos, groups, events, wall posts, status updates, and soon. " (Facebook's mission is to give people the power to share and make the world more open and connected. Four years ago, we built new products that help people communicate more, such as photos, videos, events, post messages on Facebook wall, updating status, and so on.)

Facebook has various advantages, including the following: a. The ability to build a group network more quickly and informatively. b. Network services can be sorted according to our position. From the start, the account creation is adjusted based on the country. We are making it easier to make friends. C. Group services on Facebook are more focused. Where to form an online community such as wall-to-wall testimonials, photos, discussion forums, and so on. d. Selling service, which means as a place to offer goods to Facebook users. e. Status update service, anytime and anywhere, most notably online. f. Mobile access service is a service for mobile with a feature to send a message/information. g. Chat service (commenting on and responding to each other) communication with Facebook users who are online.

Academics have significantly benefited from the emergence of social media. Various information, references, journals, and research results published through social media are available in abundance. The emergence of social media is not a substitute for the education system. But the presence of social media is more supplementary and complementary or a medium to facilitate access to information. Based on social media's role, it can be concluded that the role of mass media in social life is not just a means of diversion, tension release, or entertainment, but the content and information presented has a significant role in the social process. The content of social media is brain consumption for the community so that what is on social media will affect the subjective reality of the actors of social interaction. It is undeniable that social media ( Facebook in it) in media development has taken a form that rivals conventional or traditional media, such as television, radio, or print media. This advantage can occur because social media does not require many workforces, large capital, and is not bound by massive production infrastructure facilities such as offices, buildings, and other reporting equipment. Social media users can even be active, take a role, and be independent in determining social media content anytime and anywhere. Social media users are free to edit, 
reduce and add, distribute, and modify the text, images, videos, graphics, and various other forms of content. In 2012 Facebook users reached 1 billion and in 2014 reached 1.2 billion users. Social media has significantly impacted political progress, reform, and a better climate for democracy in many developed and developing countries. Some revolution of social and political.

With the increasing number of social media actors, it is marked that it is increasing from year to year. For netters and social media actors, this activity of spreading social information is not just for fun. Many studies have shown that social media has become a bridge to build a reputation, build a career, uncover opportunities, and generate income. This is where the deviation from using Facebook as a social media begins during society. Where Facebook is being misused to spread hoax news (Here is the empirical evidence that "... Data from the Ministry of Communication and Information states that there are around 800,000 sites in Indonesia that have been indicated as spreading false information (hoaxes)," said the Head of the NTT Regional Police, Inspector General of Police Agung. Sabar Santoso. Then he said that specific individuals had misused the internet for personal and group gain by spreading malicious content that caused anxiety and mutual suspicion in the community. (Https://krotan_mediaominfo.go.id Accessed

08/09/2020) or committing an affair that denies a legal marriage bond. Of course, this is very dangerous to social and social life. The family is the smallest social unit in community life, which will create future generations of future generations. The research was conduct about relationships between Social media and family divorce (middle-class society in Padang, West Sumatera)?

\section{Theory of Divorce}

Divorce is a process that involves many aspects such as emotional, economic, social, and legal recognition by the community through laws that apply like a marriage. According to Spanier and Thompson (1984), divorce is a reaction to a marriage relationship that is not going well and is not a disapproval of the institution of marriage. Research conducted by Murdock (1950) on the comparison of divorce in developing countries concluded that in every society, some institutions/institutions complete the process of ending a marriage (divorce) as well as preparing for a wedding. In contrast to Mudorck, Goode said that every society has a different definition of conflict between husband and wife and resolved. Goode himself argues that the view that divorce is a "failure" is biased because it solely bases marriage on romantic love (Erna Karim) in (TO Ihromi, 1999: 135). All marriage systems consist of at least two people who live and live together, each of whom has desires, needs, passions, and social backgrounds and values that may differ from one another. As a result, this system can create tensions and unhappiness felt by all family members. We can conclude that divorce is a legal and permanent termination of the marital relationship. Although at first the parties in a marriage agreed to seek happiness and continue the offspring and want to live together until the end of life, often such desires run aground in the middle of the road by various things (Drs. Lili Rasjidi, SH, LLM, 1983: 4). Through article 38, the Marriage Law number $1 / 1974$ states three reasons that can result in marriage termination, namely death, divorce, and court decisions. As a result of the end of one party, the marriage is cut off. However, a similar incident is a divine destiny, sooner or later, all humans will experience death, and every human being cannot escape from the creator's face. It is different from the termination of a marriage due to divorce and court rulings. Often the laws regulate them strictly. Therefore the purpose of enacting the law itself is precisely to perpetuate the marriage and limit divorce.

Article 39 The Marriage Law requires that to conduct a divorce, there must be sufficient reason that the husband and wife will not live in harmony as husband and wife. The reasons that can be used to sue for divorce are described in the explanation of the article and article 19 of Government Regulation number 9 of 1975 concerning the Implementation of Law number 1 of 1974 concerning marriage. These factors include 1 . One party commits adultery or becomes a drunkard, is addicted to illegal drugs, gamblers, and others who are difficult to cure; 2 . One of the parties leaves the other for 2 (two) consecutive years without the other party's permission and valid reasons or for other reasons beyond his will; 3 . 
One of the parties is sentenced to 5 (five) years imprisonment or a heavier sentence after the marriage takes place; 4 . One party commits cruelty or severe maltreatment against the other party; 5. One of the parties has a physical disability or disease, which results in the inability to carry out his obligations as husband/wife; 6 . There are continuous quarrels and fights between husband and wife, and there is no hope of living in harmony again in the household. However, Facebook, like social media, also contributes to the potential for divorce. It is evidenced that around 2005, social media became a new trend in human interaction. This trend that is in demand by young people has become so popular until now. It is not uncommon for married couples to meet through social media, one of which is Facebook. Thanks to Facebook, a human couple can be tied in a marriage rope, but it is not uncommon to cause a couple to separate or divorce. As reported by Cosmopolitan ( https://www.fimela.com . Acce ssed 08/09/2020), social media is proven to be one of the causes of stress and the cause of couples marrying dating apart because most teams who fail to move on will continue to stalk their ex on social media. Moreover, if someone was knitting communication again and happen, Blooming Love ever ends before. That is why Facebook is a factor in causing someone's divorce. A Leeds law firm, Lake Legal, reports that one-third of the divorce cases they handle, clients are active on social media and use social media sites to search for past lovers. As a partner manager, Lyn Ayton said that social media provides a continuous log of users' lives. Various written posts and pictures, geo-tagged settings provide activity records that can be used as evidence in court cases. Some cases reveal on Facebook, post status not related to anyone but invite everyone to a thanksgiving anniversary party with his girlfriend, and that's ridiculous.

Therefore, Facebook provides settings to protect your profile, and not just anyone can see your profile. If you want to be completely free of your ex, all you need to do is protect your Facebook profile from your ex's reach. Thus, someone who is married or has a boyfriend is no longer prone to face separation due to social media. The main problem faced by ex-husband and wife after divorce is a readjustment to their respective roles and their relationship with the social environment (social connection). The study of the problems and challenges faced after the divorce was carried out by Waller (1930), Goode (1956), Bohannan (1970), Krantzler (1973), Bloometal (1979), and Spanier and Casto (1979) (Erna Karim) in (TOIhromi, 1999: 156). Goode (1956) observed the readjustment process in terms of changing roles, where after a divorce, a person leaves the part of a husband or wife and takes on a new position. Besides, Goode also saw the changes in social relationships where they were no longer a married couple.

According to Goode, this readjustment includes the efforts of those who are divorced to become someone who has individual rights and obligations, so they are no longer an ex-husband or ex-wife. Constance Ahrons (1979) suggests that the bonds between the child and the father-mother no longer at home form a family system called "a binuclear family system." This family system consists of two primary families: the child's orientation family and remaining in touch with each other. Each of these families has the right and obligation to care for, care for, and educate their children. The center of child orientation between the two families depends on the agreement between the ex-husband and wife. Some determine that the father's family is the primary orientation's family than the mother's family or vice versa. The father's family has the same orientation position as the mother's family.

According to a psychological perspective, Cole (2004: 6) argues that says there are six significant negative impacts felt by children due to divorce, namely: a. Denial Denial is one of the most frequently used ways to deal with emotional wounds and protect him from feelings of betrayal and anger. The prolonged denial is an indication that the child believes that he or she is the cause of the divorce that occurred in the parent. b. Shame Shame is an emotion that focuses on defeat or moral denial, envelopes one's shortcomings, and contains a state of passivity or powerlessness. c. Guilt Guilt is a feeling of wrongdoing as an emotional attitude, which generally concerns personal conflicts arising from controversy or imagined from moral or social standards, either in action or thought. This feeling 
emerges because of unfulfilled expectations, acts that violate prevailing norms and morals, and activities contrary to conscience. Children usually believe more than their parents' divorce was caused by themselves. Even though older children already know that the divorce was not their fault, they still feel guilty for not being a better child. d. Fear Children suffer from fear due to their helplessness and helplessness caused by the separation of both parents. Children show this fear by crying or holding on tightly to their parents or needing to depend on a favorite object such as a doll. e. Sadness Sadness is the most profound reaction for children when their parents are separated. Children will be perplexed when their parent's relationship is not going well, especially if they continue to hurt physically or verbally. f. Anger/anger: Some children express outrage at the parents they live with because they feel safe taking their frustration out on the parents who did not leave them. Children usually blame their parents for causing fear to them because of the many changes after the divorce.

Next, the causes of divorce are various kinds, ranging from incompatibility, material matters, domestic violence, family pressure, infidelity, and so on. In today's world, the cause of divorce is rife in social media. As reported by yourtango.com, a survey conducted by the American Academy of Matrimonial Lawyers ( https://www.fimela.com A ccessed 08/09/2020) said that lawyers noted divorce to social media increased by 80 percent; social media there are many kinds, ranging from Facebook, Twitter and so on. Who would have thought that this could be the cause of the separation of husband and wife? A lawyer for a divorce, Victor A. Garnice, said that many people carry proof of status or photos on social media to reinforce their desire to divorce. Even divorces occur because the husband or wife is considered negligent and prefers to linger on social media updates rather than care about their children or husbands. Allegations such as cheating on tagged photos and intimate statuses can lead to fights between husband and wife. This is further complicated if the husband or wife brings household problems to the classes, even quarrels on Facebook. It is even sadder when the two insult each other and read by their relatives on social media. Technology can be useful and misleading. It's up to you how wisely you use social media.
According to a recent survey (https://www.beritasatu.com Accessed 08/09/2020), almost 33 percent of divorced couples include Facebook in the cause of their divorce, at least that's the result of research from Divorce Online on 5000 divorce documents submitted by the firm. -Firma attorney in the United Kingdom. "If someone wants to cheat or seduce a sexual partner, then Facebook is the easiest place to do it," said Mark Keenan, a spokesman for Divorce-Online. Facebook statuses or suspicious restaurant "check-in" locations and photographs of unusual places are common grounds for suing for divorce. "People have to be careful what they have deaf on their wall because the judge will use that as evidence to decide disputes over gono-gini and child custody," explained Keenan. Apart from the UK, according to the American Academy of Matrimonial Lawyers, about 80 percent of divorce lawyers said the number of cases using social networking excuses has indeed increased sharply. "I have often witnessed the problem of Facebook being the cause of divorce," divorce lawyer Gary Traystman told Smartmoney.com. Of the 15 divorce cases it resolves each year, 60 percent of them are related to Facebook. K. Jason Krafsky, the co-author of the book "Facebook and Your Marriage," also confirmed this trend. He said that in-office and out-of-office affairs often take a long time to grow, can now happen in just a few clicks via Facebook. "On Facebook, all that happens in a few clicks," said Krafsky.

Social media is a place to show competition and jealousy among friends or acquaintances in cyberspace. Many people who are having problems with their partner confide their hearts through their status on Facebook. This is what sparked the fight.

Lawyers from the law firm Slater and Gordon in the UK say social media is a minefield for new marital relationships. Chatting on Facebook can also lead to conflict in relationships because of its confidential nature. You can send personal photos but cannot look for them as evidence because the conversation cannot be saved. Based on various surveys, studies, and research that have been done earlier above, it gives a negative image of face book on the incidence of divorce. 
This is a separate note for a study that provides another possibility to see that social media (Facebook) is only a medium used by humans in social interaction in cyberspace. Facebook is only a means of creating this social interaction. Simultaneously, as operators or the main subjects who use Facebook, humans also need to be seen as a determining factor for the occurrence of an affair that leads to divorce. This means that experience will not occur and lead to divorce unless the human being wants the matter itself (Who is the man behind the gun). Therefore, this study was conducted to clearly see the problem and not take sides in accepting or rejecting the possibility of Facebook as an intermediary for the occurrence of an affair, which has led to a divorce gap in the family.

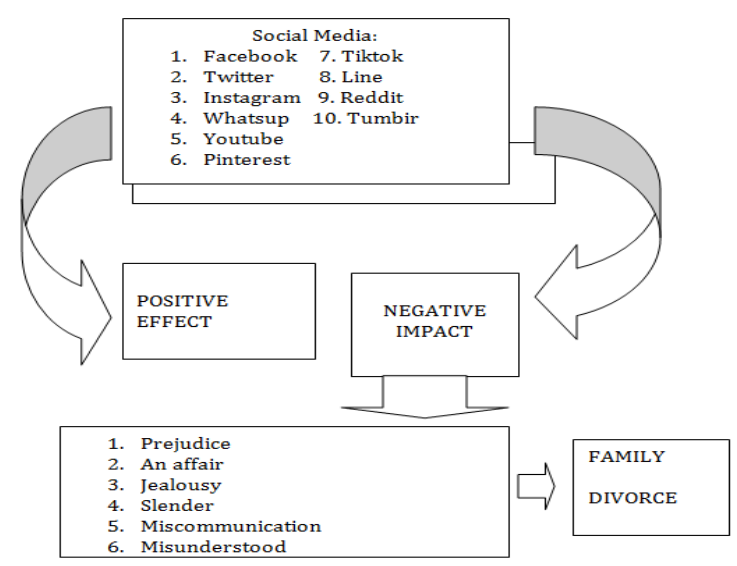

Figure 3. Conceptual Frame-Work

The causes of divorce can be various, ranging from incompatibility, material matters, domestic violence, family pressure, infidelity, and so on. in today's world, the cause of divorce is rife in social media.
Social media is a means of communication for a person to represent himself and interact, collaborate, share, communicate with other users, and form virtual social bonds. The more sophisticated social media is, the more opportunities for someone to have an affair that starts with trivial things such as commenting on the status and indirectly giving attention. In the end, the interaction provides comfort between them, which leads to mutual attraction to each other, and decides to have an affair on the pretext that no one will know an experience even happens to their partner (Nasrullah, 2015).

\section{Method}

This study uses a quantitative descriptive approach. The population in this study were 368 people, while the study sample was 191 people. The technique of collecting data through psychological scales and interviews. Sampling technique using simple random sampling. Data analysis techniques using the Pearson correlation.

\section{Result and Discussion}

There are two types of findings in this study: (1) Descriptive respondents' and data distribution and variable mean. (2) Quantitative analysis and hypothesis testing. Subsequently, according to Sugiyono, descriptive statistics are used to analyze data in ways that describe or depict the data collected as without meaning make conclusions or generalizations apply to the public. The results of the respondent's descriptive analysis are wholly explained in table 1 below:

Table 1. Analysis of Descriptive of Respondents

\begin{tabular}{llll}
\hline & Category & Frequency & Percentage \\
\hline $\boldsymbol{1}$ & Gender & & \\
& Woman & 127 & 66.49 \\
& Man & 64 & 33.51 \\
& total & 191 & 100.00 \\
2. & Education Level & & \\
& Post Graduate & 32 & 16.75 \\
& Bachelor & 118 & 61.78 \\
& Senior High School & 41 & 21.47 \\
total & 191 & $\mathbf{1 0 0 . 0 0}$
\end{tabular}




\section{Income level \\ > Rp. 16,000,000 $\quad 22 \quad 11.52$ \\ IDR $11,000,000$ up to IDR $133 \quad 69.63$ \\ $15,000,000$ \\ IDR 5,000,000 up to IDR $36 \quad 18.85$ \\ $10,000,000$ \\ total 191 \\ Source: Research Report 2018}

Table 1 above illustrates that most respondents are female (women), ie as many as 127 people, equivalent with to sixty-six points fortynine percent $(66.49 \%)$. Male respondents as many as 64 people or equal to thirty-three point fiftyone percent $(33.51 \%)$. It means that most male respondents involved in the study are smaller compared to female respondents.

Based on the level of education, it can be seen that, in general, the respondents were educated, undergraduate. Namely as many as 118 people or equivalent to sixty-one point seventy-eight percent $(61.78 \%)$. While respondents with postgraduate education only amounted to 32 people or equal to sixteen points seventy-five percent. When respondents who are educated in Senior High School are as many as 41 people or equivalent to one point forty-seven percent $(21.47 \%)$, this shows that respondents are generally categorized as highly educated.

If observed from the level of income, the respondent's main dominance is between Rp. $11,000,000$ to Rp. 15,000,000, where they amount to 133 people, equivalent to sixty-nine points sixty-three percent $(69.63 \%)$. Whereas respondents with an income of IDR 5,000,000 up to IDR 10,000,000 are 36 people, equivalent to eighteen points eighty-five percent $(18.85 \%)$. When respondents who earn> Rp. 16,000,000.- as many as 22 people or equivalent to eleven points five hundred two percent $(11.52 \%)$. As for the spread of mean and frequency and percentage of use Facebook by sex at middle-class people in Padang are outlined below:

Table 2. Distribution on Using Facebook of Middle-Class Society in Padang

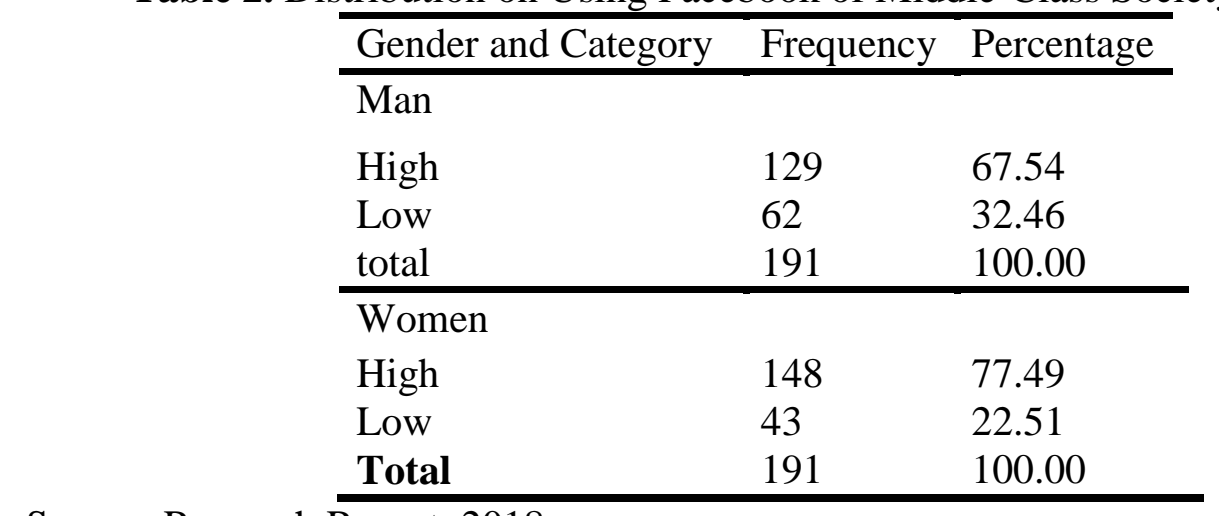

Source: Research Report, 2018

According to Table 2. above, it can be seen that generally, respondents have a high level of social media usage (Facebook). In male respondents (male), the level of Facebook use is classified as high as many as 129 people or equivalent to sixtyseven points fifty-four percent $(67.54 \%)$. At the same time, male respondents who have a lower level of Facebook users are much less. Namely, as many as 62 people or equivalent to thirty-two points forty - six percent ( $32.46 \%)$. When female respondents generally also have a high level of Facebook usage. The description of the data evidences this. One hundred fortyeight people classified as having a high level of use of Facebook or equal to seventyseven point forty-nine percent $(77.49 \%)$. 
Simultaneously, the respondents who have a low Facebook level use as much as 3 or 4 equivalent to twenty-two points fifty-one percent (22: 51\%). It means that Facebook's use in the middle class in Padang City is high, while women dominate Facebook's service among the middle class in Padang. The explanation of the results of the analysis of the distribution of frequency and average and the percentage of divorce in the family among the middle-class people in the city of Padang is described as follows :

Table 3. Distribution of Divorce in the Family at the Middle-Class Community in Padang City.

\begin{tabular}{lll}
\hline Category & Frequency & Percentage \\
\hline High & 61 & 31.94 \\
Low & 130 & 68.06 \\
total & 191 & 100.00 \\
\hline
\end{tabular}

Source: Research Report s 2018

According to Table 3 above, it can be seen that low categories generally dominate the level of divorce in the city of Padang or as many as sixtyeight points zero six percent $(68.06 \%)$. While the spread of the mean and frequency of infidelity in the high grade is only 61 or equal to thirty one point ninety-four. This means that divorce among the middle class of Padang City is generally still relatively low. Furthermore, the hypothesis testing analysis of the correlation between the two variables (the use of Facebook and divorce in the middle-class family of the city of Padang) got that I r count $=3.86<$ r table 5.92, which means there is no relationship between the use of Facebook and divorce in the family in the middle social class in the city of Padang.

This means that there are still other variables that allow the correlation between the two variables. For example, type of work, length of the marriage, and offspring, loyalty, and religious grip. As we know that, the kind of work that requires a husband or wife too far apart allows limited information between the two. So that suspicion arises when they have difficulty communicating so that the type of work is also thought to be the decisive variable between the formation of a correlation between Facebook use, which leads to divorce among the middleclass people of the City of Padang.

Furthermore, the length of the marriage is thought to contribute to the decision to divorce. In a married couple who have been for decades, of course, there have been embedded trust between the two. Compared to a new marriage "for corn." Therefore the duration of the transfer is also expected to affect the relationship between the use of Facebook and divorce among the middle-class people of Padang City.

Whereas children's presence is often assumed to be the glue of the relationship between husband and wife. So that the absence of children is also thought to be a reinforcement of the link between the use of Facebook and divorce in the middle class of the city of Padang, next, loyalty or loyalty between husband and wife to maintain family permanence is also a factor that is thought to influence the relationship between the use of Facebook and divorce among the middle class of Padang City. Finally, religion's grip here means the extent to which the faith embraced, not just the truth. Then, he also carried out the order so that the individual concerned, both husband and wife, tried to maintain the sanctity of the marriage that he passed from the act of sin of adultery. Various factors that are thought to be determinants for the relationship between the use of Facebook and divorce among the middle class of Padang City need to be studied more deeply by other researchers and not explicitly discussed in the research that the researchers run.

\section{Conclusion}

Although this study found a high level of Facebook usage among the middle-class people of Padang City, it does not necessarily give birth to a high divorce among community members. It means that the level of separation among the middle class is relatively low. Furthermore, using Facebook is more often used to develop business or trade. It means that Facebook is used more on the marketing of trade products that they run. Even if there are high Facebook users involved in infidelity cases that lead to divorce, this is only casuistic or occurs in some instances. Where this generally occurs in the lower-middle-class society in the context of 
the people of Padang City. Thus the technological advances in the current Industrial Revolution 4.0 era, which are accepted by the class community to prevent the City of Padang, are generally positive in which people manage Facebook professionally to attract new customers or retain existing customers so that Facebook is productive to increase family income.

This study's findings also found that there were still divorces among middle-class members of the Padang City family. So it is necessary to explore the various possibilities that trigger divorce so that you need to anticipate earlier so that there is no divorce. As a society that holds Adat philosophy jointed with the Shari'ah and Shari'a jointed Kitabullah (AS-SBK). The middleclass people of Padang City still uphold Islamic values as a handle or practice in behaving amid the community. Thus the affair is still considered a discordant event that cannot be tolerated. Besides that, traditional leaders and smart-people (Cadiak-Pandai)

and Bundokandung (motherhood), NinikMamak (parenthood) as tigosajarangan (three supreme) stoves are still protecting community members from immoral behavior or violating religious norms.

The end of what is to be conveyed through this study is that technology is only a tool or medium for the progress or decline of human civilization. So do not "scapegoat" technological progress as a decline of civilization. Therefore humans who control the technology need to be prepared so that they do not use it on negative things (such as spreading hoaxes and spreading hate speech, spreading slander, spreading pornographic images and films through Facebook ) - but optimizing technology for personal and social welfare to advance human civilization itself.

\section{References}

[1] Afdjani, Hadiono. 2007. Impact of Media Globalization on Indonesian Society and Culture. Jakarta: Budi Luhur University.

[2] Arikunto, Suharsimi, 2002, "Research Procedure, A Practical Approach,"
Publisher Rineka Cipta, Twelfth Edition, Revised Edition V, Jakarta.

[3] Cooper, Young, Griffin-Shelley, O'Mara, and Buchanan . 2000. Cybersex: The Dark Side of the Force. Philadelphia: ArunnerRoutledge.

[4] Exploration. Computers in Human Behavior, 23, 11-31.

[5] Fahmi, R. 2019. Social Media and Family Divorce. Majalah Ilmu Pengetahuan dan Pemikiran Keagamaan Tajdid.UIN Imam Bonjol Padang. Vol. 22 No. 2 . p. 154161.

[6] Fahmi R. And Aswirna, P. 2019. The Effect Of Youtube Social Media On Religious Commitment Towards Padang City Students In West Sumatera, Indonesia. www.researchgate.net. DOI: 10.13140/RG.2.2.15270.98888

[7] Giddens, A., 1997. Sociology. New York: Polity Press.

[8] Kusumadewi, Niken Olivia. 2010. Parents and Adolescent Communication Experiences in Understanding the Impact of Using the Facebook Social Networking Site. Semarang: Department of Communication, Faculty of Social and Political Sciences, Diponegoro Univer sity.

[9] McQuall, Denis. $2010 . \quad$ Mass Communication Theory. Singapore: SAGE Publications.

[10] Miller, RS, Perlman, D., \& Brehm, SS, 2007. Intimate Relationship 4th Edition. New York: McGraw Hill.

[11] Nasrullah, R. 2015. Media Sosial Perspektif Komunikasi, Budaya dan Sosioteknologi. Bandung: Simbiosa Rekatama.

https://scholar.google.co.id/citations?user= -eLCSIAAAAAJ\&hl=en.

[12] Papalia, D., 2007. Human Development 10t h Edition. New York: McGraw Hill.

[13] Singgih D. Gunarso, 1991, Developmental Psychology, Jakarta: PT. BPK Gunung Mulia. 
[14] Sutopo. HB. 2002. Qualitative Research Theoretical and Practical Bases. Surakarta: UNS Press.

[15] Turner, JS \& Helms DB 1995. Lifespan Development 5th ed. USA: Harcourt braces college publishers.

[16] Underwood, H. \& Findlay, B., 2004. Internet Relationships and Their Impact on Primary Relationships. Journal of Behavior Change, 21 (2), 127-140.

[17] Wirawan, Sarwono, Sarlito. 2006. Social Psychology .; Individual and Social Psychological Theories. Jakarta: PT. Balai Pustaka.

\section{About the Author/S}

Reza Fahmi (Scopus ID: 57216268447) He is a senior lecturer in the Department of Islamic Psychology, Faculty of Ushuluddin and Religious Studies, Imam Bonjol State Islamic University, Padang. Active in participating in international conferences, this is evidenced by the author's invitation as a speaker at the AICIS (Annual International Conference on Islamic Studies) event nine times in a row. I had published 40 local, national, and international journal articles. It disseminated research results 28 times in various cities in Indonesia and abroad (Turkey, Malaysia, United Kingdom, Bosnia). I'm involved in 35 research, regional, national, and international.

Dr. Prima Aswirna, S.Si. MSc. (SCOPUS Author ID 57216270393) is a senior lecturer in Physic Education in Tarbiyah Faculty at UIN Imam Bonjol Padang. She has been joint the Annual International Conference on Islamic Studies (AICIS) nine times continually. She had done twenty-sixth research sponsored by the local institution (UIN Imam Bonjol Padang), national institution (Religious Affairs Dept.), (Ministery of Education), and self-funded. She wrote a thirtyseven article published in a local, national, and international journal-her interest in educational science and family studies. 